\title{
Local War History Materials in College and University Libraries
}

The librarian of Miami University has assembled a suggestive report on the treatment of local items relating to the war.

W

ORLD WAR II, surpassing all previous wars in scope and fury, promises also to be the most systematically documented war in history. The motion picture and sound recording, the microfilm camera, together with the usual media of pen and press and typewriter, are leaving us with what threatens to be an embarrassment of historical riches." ${ }^{\prime \prime}$ Historical sections have been organized for all branches of the armed forces and provision made for securing and processing all materials necessary to the compilation of extensive operational and administrative histories.

Can the same confident note, however, be sounded with regard to the collection and preserving of local war history materials by college and university libraries? In an effort to discover by sampling to what extent local history materials are being preserved by these libraries, letters were written to fifty representative colleges and universities in all sections of the country. Communications also were sent to some forty state historical commissions, state departments of archives and history, and state libraries. A few national organizations, such as the American Association

1 "Plans for the Historiography of the United States in World War. II" in ". Notes and Suggestions . . American Historical Review 49:243, January i 944 . for State and Local History, responded to requests for information.

The replies received from college and university librarians registered a wide variance in interest and activity, which was to be expected because the extent of a library's local war history collection is dependent on the size of the library and its nature and on the community and state in which it is located. A few libraries which had zealously collected the records of World War I only to see them unused and gathering dust are decidedly lukewarm about starting a similar project. One librarian even goes so far as to express the opinion that such activity is "pure busy work." Others, however, are interested and are "doing what they can," but are handicapped by lack of staff and space. Some libraries report that they always have collected local history materials and will continue to do so but are making no special attempt to preserve the records of this war. A few take comfort in the thought that other agencies on the campus, such as the alumni office and the publicity bureau, cover the field so well that little is left for the library to do. Frequent mention is made of a strong public library in the same community which is collecting local war records, thereby leaving the college library responsible chiefly for obtaining the war records of its own institution. The local war history programs of the larger univer- 
sities, some of them with regularly appointed "war historians" or "curators" of their war literature collections, are too ambitious for the smaller college library to emulate, but there are certain fundamental local records relating to World War II which it would seem every college should collect and preserve.

A sensible preliminary step might be for each college library to critically survey its previous war collections, particularly that of World War I, noting their obvious lacks as well as the items of most interest and value. To obtain a picture of the nationwide collecting activities during the First World War, Lester J. Cappon's article on "The Collection of World War I Records in the States"'2 and Waldo G. Leland's "Historians and Archivists in the First World War"3 merit careful reading.

Every college library certainly should be in close touch with its state historical commission or with whatever administrative agency is heading up the war records project in its state; it should ascertain the extent of the state, county, and outstanding community collections, and thus avoid unnecessary duplication of effort.

\section{Initial Stimulus}

The initial stimulus-on a nationwide scale-to the formation of war records projects in the states was given, shortly after Pearl Harbor, by the Social Science Research Council's Committee on the Control of Social Data, which later functioned under the sponsorship of the Committee for the Conservation of Cultural Resources. These committees have encouraged the state historical commissions

\footnotetext{
2 Cappon, Lester J. "The Collection of World War I Records in the States." American Historical

Review 48:733.45, July "I043.
\& Leland, Waldo G. "Historians and Archivists in the First World War." American Archivist 5:1-17, January I942.
}

and other administrative agencies to direct and act as coordinating agencies in the collection and preservation of World War II materials in local communities. The American Association for State and Local History, through its special Committee on State and Local War Records, also is making an effort "to encourage the various state war records projects throughout the country and to serve as a central clearinghouse." This committee, under the chairmanship of Dr. Cappon, has just issued a report on "War Records Projects in the States I94I-I 943"4 and also the first number (March 1944) of the War Records Collector.

Some of the war history manuals issued by the state historical commissions are helpful, although of course they contain many categories for collecting that apply chiefly to public and historical society libraries. The following states are among those which have distributed publications which seem particularly useful: The Iowa State Department of History and Archives has issued a "War History Manual"5 and also separate publications on the clipping file ${ }^{8}$ vertical file, ${ }^{7}$ and preservation of war records. ${ }^{8}$ New York, through its division of archives and history, has published a fairly extensive "War Records Handbook." The North Carolina Office of Civilian Defense, in cooperation with the state department of archives and history, has distributed a "War Records Man-

\footnotetext{
- Cappon, Lester J. "War Records Projects in the States 194I-1943." Bulletins of the American Asso. ciation for State and Local History 1:189-226, March

1944. Iowa State Department of History and Archives. "War History Manual." August 1943. 8p.

- Iowa State Department of History and Ärchives. "A War Information Center Clipping File." August I942. I I p.

Iowa State Department of History and Archives. "A War Information Center Vertical File." Sep. tember 1942. $12 \mathrm{p}$.

8 Iowa State Department of History and Arrhives. "Preservation of Materials for War Records World

War II." September 1942. 8p. 8. Pepartment. Division of Archives and History. "War Records Handbook." 1943. 3 I p.
} 
ual"10 and also special bulletins. The Pennsylvania Historical Commission has a "War History Manual,"11 and the Wisconsin War Records Commission a "War Records Manual."12 Bulletin Number Seventeen of the Michigan Historical Commission is entitled "War Records World War II."13 The Ohio War History Commission distributes to its county and local chairmen a monthly bulletin "Communikay"14 instead of a manual. This commission, moreover, has a useful folder: "What Are YOU Doing to Preserve Ohio's War Records?"15 The foregoing are only examples of similar material which may be secured from other state commissions.

Any local war history project, no matter with what high enthusiasm it may have been started, is sure to falter without the support of an administrative committee. For the small college, a committee with representation from the faculty, alumni, student body, and library staff might be feasible.

Supported by a representative committee and guided by manuals and bulletins from state and other agencies, each library then must determine what records shall constitute its local war history collection. The materials that follow are suggestive only.

\section{Records of Alumni and Former Students in the Armed Forces}

Service Records. The service records

${ }^{10}$ North Carolina Office of Civilian Defense and State Department of Archives and History. "War Records Manual." I942. 6p.

11 Pennsylvania Historical Commission. "War History Manual." 1942. IIp. See also this commission's Pennsylvania's First Year at War. 1943 roop. "Pennsylvania's Second Year at War" is in

preparation. ${ }^{12}$ Wisconsin War Records Commission. "War Records Manual." May I943. I6p.

${ }^{13}$ Michigan Historical Commission. "War Records of Michigan World War II." Bulletin No. I7. 1943. $15 \mathrm{p}$.

V. 1 , no. 1 , July I5, I942 (In progress)

is ' no. I, July 15, 1942 (In progress).

Doing to Help Ohio Preserve Her War Records?"

I 942 . $8 \mathrm{p}$. of alumni and former students usually are kept in the alumni offices of colleges and universities. These records, secured from postal card questionnaires or special letters, naturally are more elaborate in the large institutions. A common practice is to have a master file with a separate envelope for each individual's service record and all other war information, including pictures, letters, clippings, and biographical data. For the missing and the dead, an effort usually is made to secure as complete information as possible by writing the next of kin for biographical information and photographs. Much of the material in these master files, no doubt, will remain permanently in the alumni offices. In some colleges and universities, however, arrangement has been made for the library to receive letters of particular interest or significance for their memorabilia collections.

Letters. War letters have poured into colleges as a result of various appeals. The president's office receives numerous letters through the issuance of special messages or bulletins to alumni in the services. ${ }^{16}$ Requests for letters, likewise, are made in the alumni magazine and the student newspaper.

Because of this letter-gathering activity in the administrative and alumni offices, college libraries in general are making little attempt to collect war letters directly. But it would seem that they might take a more active part, and there are a number of well-known sources through which war letters may be obtained.

A few university libraries, among them Minnesota and North Carolina, have sought letters from former student assistants and staff members. In some

16 Wilkins, Ernest H. "Ways of Keeping in Touch with College Men in Military Service." School and Society 55:362-64, Mar, 28, 1942. 
instances these letters have been particularly interesting in that they form a series from a single individual from the time he reported at his induction center until his present post overseas.

Faculty members should be urged to turn over either to the library or to the alumni office, letters which they receive from students in the services. To round up letters, a regularly designated member from divisional faculties or departments would be helpful.

Class secretaries frequently receive war letters which are of value and interest and which might be given to the library. Fraternities and local clubs or societies on the campus are further possible sources. The faculty sponsor of the "Poet's Circle" on the Miami campus is corresponding regularly with former members now in the service and already has accumulated a most interesting file from various war theatres. Ministers, newspaper editors, and other representative citizens of the community usually are glad to give to libraries the letters which they receive.

The families of men and women in the services naturally are reluctant to give up personal war letters at this time, but arrangements might be made to have the letters, or parts of them, copied or to have them presented at some time after the war.

\section{Diaries}

The necessity of censorship, which often limits the interest and information in overseas letters, would not impose the same limitations on diaries, and any of these which could be secured-probably chiefly after the war-would be a most important addition to the local war history collection. The Miami University Library only recently secured a Civil War diary which gave a much more vivid and complete account of the formation of the "University Rifles" in May I86I than had appeared in the student paper or local newspaper of the period. Efforts made during and immediately after a war are necessary to prevent many of these valuable manuscripts from being lost.

Antioch College has under consideration an interesting project of asking each alumnus, when mustered out, to write an account of his war experiences. Even if only a small percentage of the alumni responded, the collection would be decidedly worth while, particularly if it included the accounts of men and women in the many different branches of the service and from the various theatres of war.

A most effective appeal for letters and diaries is a single sheet "reprinted with variations" from the Michigan Alumnus, I943, urging the alumni of one institution to send such materials to the university war historian. The following lines are quoted from this appeal:

Soldiers and sailors are proverbially given to letter and diary writing; they are effective epistolarians. Examples of their proficiency in this respect during Civil War and World War I days abound in the Michigan Historical Collections. ... To read these compositions is to gain a realistic conception of war with its many implications; they impart to the war the earthiness of the Army, the saltiness of the Navy. One may anticipate the breeziness of the Air Forces as well in the World War II diaries and letters which the collections hope to acquire.

Other manuscript records to be secured would include unpublished addresses, radio scripts, sermons, and the proceedings of war discussion groups and forums.

\section{Civilian Contributions of Faculty and Alumni}

Most of the college and university li- 
braries reporting state that they are making no effort to set up special collections of faculty and alumni civilian contributions to the war effort. They feel that outstanding civilian achievements are sufficiently recorded in alumni magazines, the student and local newspapers, and annual reports of the college president, as well as through the clipping services subscribed to by many college news bureaus.

It is true that most of the scientific and technical war research is at present confidential; its story cannot be told fully until after the war. It would seem, however, that alumni and faculty, now on leave, engaged in research or carrying on other work in government and industry should be encouraged to record their activities upon return to their former positions when the war is over.

Faculty members, "retreaded" to carry on the instructional programs in military service units on the campus, have made a vital contribution to the war. For the most part their work is all the more remarkable because often it has been far removed from their chosen fields. Perhaps a French professor is teaching aircraft identification or a German professor, meteorology. A paper read recently at a civilian men's club by a member of the English department, entitled "From English Literature to Practical Navigation," recorded in a most amusing and yet informative manner the story of a transplanted instructor in the Navy $\mathrm{V}-12$ program. A copy of this paper surely should be found in the war history files.

\section{Curriculum Changes}

Accelerated programs in the colleges and universities and sweeping curriculum changes, particularly in the offering of more scientific and technical courses, quickly followed our entry into the war, as higher educational institutions attempted to adapt themselves to war needs. In many colleges, because the war had been anticipated, special courses were added even before Pearl Harbor. As early as I939 students were taking pilot training on many campuses under the sponsorship of the Civil Aeronautics Authority. The Army and Navy succeeded the C.A.A. as sponsors of these courses in 1942, when they became known as the W.T.S. program. Early in 194I colleges and universities throughout the country began to offer courses under the Engineering, Science, and Management War Training Program initiated by the United States Office of Education. These E.S.M.W.T. courses, taught in nearby industrial cities by faculty members, are continuing. The records of the C.A.A. and E.S.M.W.T. programs can be obtained after the war from the files of the faculty officials in charge of them.

The University of Michigan war historian, Howard Peckham, recently has written a bulletin on "The University in the War,"17 which surveys Michigan's services to the armed forces and the home front. It is very suggestive of the different local materials which ought to be preserved.

The reports of the administrative and faculty committees on wartime curriculum changes-especially committee reports on postwar planning, of which vocational rehabilitation is one aspect-certainly should be included in the college's war history collection.

17 Peckham, Howard. "The University in the War." University of Michigan Official Publication 45 , no. 54, Jan. I 2, I 944. I 5 D. See, also, by the ords Collector I:9-10, May I 944. The most extensive survey is, of course, Evelyn S. Little's "War Activities of College and Research Libraries." College and Research Libraries 4:I79-2 I I, June 1943. 
Army and Navy Specialized Training Programs

Most of the records of the military service units on the campus, of course, cannot be obtained at the present time. As one librarian points out, "It is a question first of all what to ask for, and furthermore officers are much too busy to have time to sort out what printed material could be given." The difficulty of securing these records is further complicated by the swiftly changing personnel which heads the service organizations.

However, in the case of some units certain records can be obtained at once. For example, the Air Force requires of each unit that it write its history; a copy of this, up to date, can be secured now. The daily activities of all service organizations are recorded in their regular bulletins, papers, and yearbooks. These are available, and complete files, of course, will be kept. After the war the historical records, at least, of all the units will be available. Directives, syllabi, and textbooks of the specialized training programs could be included in the collection. Because the faculty liaison officer in charge of these training programs is in daily contact with the service officers, naturally he is in a strategic position to make arrangements for securing the records. The faculty member directing one Navy V-I2 program has promised to give the library any desired material from his files after the war, beginning with an account of his indoctrination course.

\section{Wartime Organizations on the Campus}

All college campuses abound with wartime agencies, some of them permanent like the Red Cross, some temporary like the U.S.O., and some defunct like the Finnish War Relief. In the case of defunct agencies, their records should be secured at once from the local chairmen or secretaries; and in the case of organizations still operating, definite arrangements should be made to secure their records at the close of the war. Faculty and students alike have contributed to the success of these organizations, upholding the reputation of the U.S.O. as an effective morale builder, taking their part in the local civilian defense group, submitting themselves as first aid "patients," and contributing their pint of blood many times over.

Red Cross drives, war bond and war stamp sales are examples of other wartime activities of which there should be a written record, along with posters and pictures to make them vivid.

\section{Newspapers and Periodical Publications}

The Local Newspaper. Few librarians would be likely to dispute a sentence that occurs again and again in articles on collecting war materials: "The local newspaper is the most important single record of the war."

The college library probably would wish to keep complete files of local newspapers even though they might be available also in the local public library, because the papers would have articles on the war activities of the college treated in a different way from those in the college newspaper.

Most college librarians seem to feel that if a complete file of the local paper is kept, a newspaper clipping collection of the files would not be necessary. As has often been stated: "The future writer of history will be much more interested in complete files than in clippings." One librarian writes: "As to clippings, I personally see no advantage in a collection of them if good files of local papers are kept. Such a collection is of little value unless 
it is very complete, carefully preserved, and thoroughly indexed, and I have found that even large and well-organized libraries have not enough time and help to do the job well." Probably the ideal procedure would be to make a careful index of the local papers, such as the newspaper indexes prepared under the direction of the W.P.A., but unfortunately few libraries have the staff to undertake this task.

If it is desired to maintain a newspaper clipping file in addition to the complete file of the local paper, obviously a duplicate subscription will have to be entered. Clippings, of course, may be treated in various ways. One method is to place them, loose or mounted, in manila folders, to assign subject headings, and to file them in the vertical file. Another common practice is to paste them in a loose-leaf scrapbook. For both methods, a chronological arrangement under subject should be adopted. To be usable the clipping file, whether in folders or a scrapbook, must be indexed. The Sept. 3, 1943, Bulletin of the North Carolina Historical Commission gives a brief procedure for indexing newspapers, with a suggested subject heading list. These instructions also could be used for indexing the clipping file and might be useful to the library without experience in such work. Other state historical commissions likewise treat the handling of newspaper clippings. Stanley Erikson, in his article on the "Preservation of Community War Records," 18 discusses in some detail the possibilities of the newspaper clipping collection and of scrapbook files. Scrapbooksoften containing programs, leaflets, and other material in addition to clippings-

\footnotetext{
18 Erikson, Stanley. "Preservation of Community War Records." Illinois Libraries 26:I0-I I, January I944.
}

SEPTEMBER, 1944 probably will be kept chiefly by the smaller libraries which are unable to undertake any ambitious program of collecting war materials but wish to record in some way the war activities of their institutions.

\section{Alumni and Student Publications}

Complete files of student, alumni, and administrative publications, of course, will be kept by all libraries. Many of these publications are mimeographed sheets, issued only during the war, and are somewhat elusive. As in the case of local newspapers, duplicate files of the more important publications probably should be secured to permit clipping if desired.

\section{U.S. Camp and Overseas Publications}

Only a selected number of the largest libraries in the country could hope to approach any degree of completeness in a collection of the United States camp and overseas newspapers of this war, and apparently not many of them are attempting it. One of the largest university libraries reports that during the first months of World War II, it wrote to every camp and similar organization which published a paper but received a reply in only 2 per cent of the cases and then only a few of the papers. Another great university library, however, reports extremely good results in obtaining both U.S. camp and overseas newspapers, stating that "Camp editors have been very generous in response to requests for their publications, have placed the library on their mailing list, and have sent back files of their publications."

It has been pointed out that the problem of securing the publications of camps and service units for this war is "comparatively greater than the problem for the last, because of the lack of a stand- 
ardizing influence like the Y.M.C.A. and the Stars and Stripes in the last war, and the prevalence in this war of mimeographed and similarly duplicated periodicals."

State historical societies naturally will attempt to secure complete files of all camp publications originating in their own states, while a few of the great public and university libraries, no doubt, will attempt to obtain as many as possible of the overseas papers. However, probably any college library will be interested in the files of a camp paper if edited by an alumnus or in a special issue if it happens to record the noteworthy war service of a local student. One librarian makes the pertinent warning that the paper on which these publications are printed is so inferior that they would have to be microfilmed if there were any thought of permanent preservation.

\section{Books and Pamphlets}

Copies of locally published books and pamphlets dealing with the different phases of the war usually have a limited circulation; if they are to be saved at all, they probably will have to be saved by the local library. The number of these publications will not be very great in the average college community. However, the writings of faculty and alumni on the war and on national and international problems arising from the war, issued by nationally known publishers, in all likelihood will be much more numerous. They, too, should form a part of the college's World War II collection.

The photographic section of a college's local war history collection surely would include individual and group pictures of alumni and former students in United States camps and in overseas units. Some of these photographs are now in the alumni offices or in the offices of the publicity directors, but many will find their way to the library after the war and others are now coming directly to the library.

Pictures recording the many-sided war activities of the campus should be gathered in at every opportunity. Fortunately, alumni magazines, college newspapers, and especially yearbooks record pictorially the college life in wartime. Colleges usually have an official photographer who is particularly busy these days, and to his photographs should be added the contributions of the numerous amateur camera fans who inhabit all college campuses. One librarian reports good results from visits to the local photographic studios, a source that easily might be overlooked.

Many colleges and universities have made moving picture films showing the activities of the wartime campus. Some of these are made frankly for advertising purposes, but, nevertheless, they will be graphic records for the war history collection.

The photographic record of the Army and Navy service units on the campus probably will be unusually complete because their classes, drills, parades, and athletic contests are filmed on every possible occasion.

It is hardly necessary to add the caution that the persons in the photograph and the place and date should be noted carefully on the back of the picture. We all have had the experience of attempting in vain to identify some "native" from an early campus "shot," because such information was lacking.

\section{Posters, Dodgers, Leaflets, and Music}

Posters. All libraries are deluged with posters from the Office of War Information and other agencies, but it is those of local origin which each college library 
should make a determined effort to procure for its war collection. These should include organizational posters, such as those of the local civilian defense group, special posters made under the direction of the art department to aid in the countless war "drives" on the campus, as well as the hundreds of everyday varieties thumbtacked onto college bulletin boards throughout the school year. Posters must be snatched in time or they will be gone forever. All campus organizations should be asked to save their posters for the library collection. It probably will be necessary to weed out the stacks of local posters rather carefully, because, as one librarian remarks: "Posters are decorative and interesting but they are expensive to preserve." It is essential to have special oversized cabinets or files to care for them properly.

Dodgers, leaflets, and special bulletins unquestionably comprise a graphic and often entertaining side of a war history collection, even if they are of themselves of no great importance. The library "rescued" one special notice from the president's office which is amusing to read now but seemed serious enough at the time. Shortly after Pearl Harbor the faculty on many campuses were "jittery" about rumors that the college would be taken over in entirety by the Army or Navy and that everyone would lose his job. On the Miami campus the faculty started streaming in panic to the president's office for some official word. Finally, in desperation, the president issued an official notice which he tacked up outside his door; the conclusion was the comforting reminder, "Someone has said that most of our troubles never happen." Already the dodgers announcing blackouts and air raid drills seem to belong to a strangely remote past.
Music. War, as always, stimulates the writing of countless songs. Copies of any war songs composed by the alumni or faculty naturally would be secured. Photostats of the original music manuscripts would add interest to the items.

There is a decided lack of enthusiasm among college and university librarians for collecting museum material, such as war relics and trophies. These definitely have their place but, since they will be sought and cared for by state and local museums, they probably have little fitness in the average college library. However, a few trophies of the war undoubtedly will be presented to all college libraries and in many cases will be accepted. It is true that they do add a certain amount of "window dressing" to special exhibits. Miami has one service flag which is, to say the least, unique. A certain member of the faculty, rejected for military service because of a stomach ailment, was presented with a strange service flag by his colleagues, on which the "heraldry" consisted mainly of a large " $4-F$ " together with a graphic representation of the afflicted organ.

\section{Arrangement of Collections}

The methods of arranging the local history materials of World War II naturally vary with different libraries. The tendency seems to be in some of the smaller institutions where the collection is not large to keep them together as a unit or to incorporate at least a large part of them in the college memorabilia collection. In many of the larger universities, however, no such attempt is made. Books and pamphlets are cataloged and sent to the regular stacks, periodicals go directly to the periodicals room, and archives to the archives division. The great mass of miscellaneous publications, including clip- 
pings, leaflets, and mimeographed releases, are arranged, usually by subject, in vertical files or pamphlet boxes. One large library, however, is using not a subject but an alphabetical arrangement which is in most cases alphabetical by producing agency. Because of its enormous quantity, it is not possible to catalog much of this miscellaneous material at present. Certain librarians state frankly that they are not ready to say what the final disposition of it will be. It may be kept together as a unit or may be distributed, dependent somewhat upon how and by whom it will be used.

The libraries which have served as war information centers, of course, have accumulated local, as well as state and national, war materials. These war information collections may never be broken down into localities. Libraries may feel that they are more significant under subject arrangements.

Mount Holyoke reports the following arrangement, which seems to handle the disposition of the local war history collection rather neatly:

We have already set up two collections of material relating to the history of events and people connected with the college, one for manuscript and one for printed material. These have their own classification schemes which include definite places for the wars we have experienced. The material we receive automatically falls into those assigned places.

Archives and Libraries ${ }^{19}$ has had helpful articles on the preservation of local historical manuscripts and archives which are suggestive, even for small collections where only the simplest cataloging is necessary.

10 See in particular Archives and Libraries for the years 1938 and 1939 .
It should be emphasized that only those types of material have been listed which it seemed every college and university library might wish to have represented in the World War II collection of its own institution. If, as suggested by Dr. Cappon, the college library should broaden its local history activities to include also the records of the local community, as distinct from the campus, then many more types of records will need to be added to the list. Dr. Cappon's views are stated in a recent letter in which he says:

I think every higher educational institution should be urged to take the responsibility for preserving not only its own records but all materials pertaining to the town, city, or county in which it is located.

But, as was said earlier, the different state war history manuals list the types of local community records so completely that it does not seem worth while to repeat them here.

In an article on "The Local History Museum and the War Program,"20 Arthur C. Parker remarks that "Collecting is an art that only a trained person should attempt to practice. Anyone can collect promiscuously but it takes clear thinking to collect systematically with an end in view." Most college librarians probably will find that they have done a certain amount of "promiscuous" collecting in assembling their World War II material and that they have on their hands many "throwaways," the best place for which is the wastebasket.

Dr. Overman has stressed that in this war we should not resort to the common practice of World War I when records

(Continued on page 330)

20 Parker, Arthur C. "The Local History Museum and the War Program." Bulletins of the American Association for State and Local History $\mathrm{x}: 84$, October 1942 . 
It is hoped that the success of this initial venture will encourage further coordination in the serial field and eventually lead to a cooperative union catalog of all holdings. For the time being, however, the librarians realize there is yet much to be done with serials. Work may now begin on allocating broken files to those libraries that need them most; draw- ing proper lines of demarcation for future purchasing; eliminating unnecessary duplications of both subscription and binding; building up adequate collections of titles which are not now available in the region; and of generally perfecting plans for smoothly coordinated systems of acquisitions interchange and interlibrary loans.

\section{Local War History Materials}

(Continued from page 300)

often were collected only to be stored haphazardly in cartons. But if a college library is so understaffed that it can do nothing except store its war materials at present, it would be advisable, nevertheless, to continue collecting them, hoping that they may be processed after the war.

The importance of continuing the task in the postwar period should be emphasized. A very real danger is that after the war there will be a sudden letdown. The disintegration of the whole war machinery after the armistice in World War I has been compared to the dispersion of a crowd after a football game. The excitement is over and everyone is eager to get home. Yet it is only after the war that many of the most important records can be obtained, such as war diaries, letters, and files of wartime service organizations. One should remember, too, that it is a long-range program, "The collection of research materials is a continuous task. ... We should avoid the narrow viewpoint that generally prevailed ... (during World War I) of dissociating materials of the war years from those before or afterward." 21

21 Cappon, Lester J. "A Plan for the Collection and Preservation of World War II Records." Social Science Research Council, October I942. 9p.
The day-after-day assembling of war history materials often may seem unimportant and burdensome to the small college library, "bound to be hit harder than any other library by this war and its aftermath." "22 But the events which are recorded in these materials are not unimportant. Certainly no more active or interesting local history period is likely to occur for many generations. Historians of the future will draw heavily on local war history collections, particularly for the human and personal side of the conflict.

22 Hirsch, Felix E. "Smaller College Libraries and the War." Library Journal 68:192, Mar. I, 1943.

\section{References}

The following additional references. not included in the footnotes, have been found helpful:

Beeson, Lewis. "Collecting War Records." Chronicles of Oklahoma 20:174-76. June I942.

Bronicles of Oklahoma $20: 174-76$, June I942. tory." Archives and Libraries, 1939, p. 34-4I. (A good background article.)

Erikson. Stanley. "The War Records Program of the Illinois War Council." Illinois Libraries 25:

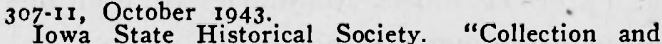
Preservation of the Materials of War History." Its Bulletin of Information Series No. 8, 2d rev. ed., Buwa City, Igrg. I op. (Originally published during World War I but still one of the best general statements.)

Overman, William D. "The Ohio War History Commission." American Archivist 6:28-33, January I943. -nith. G. Huhert. "The Tocal Historical Snciety in Wartime." Minnesota History 23:16-19, March I 942.

Stevens. Sylvester K. "Local History and Win. ning the War." Bulletins of the American Association for State and Local History $1: 27-50$, January 1942. 